\title{
O CABIMENTO DO INCIDENTE DE RESOLUÇÃO DE DEMANDAS REPETITI- VAS NO ÂMBITO DOS JUIZADOS ESPECIAIS ESTADUAIS ${ }^{1}$
}

\section{THE SUITABILITY OF THE INCIDENT TO SOLVE REPEATED DEMANDS ON CASES FROM THE SPECIAL STATE COURTS}

\section{Ciro Antonio das Mercês Carvalho}

Mestrando em Análise de Discurso pelo Programa de Pós-Graduação em Letras: Linguagens e Representações da Universidade Estadual de Santa Cruz (PPGL-UESC). Bolsista da Fundação de Amparo à Pesquisa da Bahia (FAPESB). Pós-graduado em Direito Processual pela Pontifícia Universidade Católica de Minas Gerais (PUC-MG). Advogado. Itabuna/BA. Email: cirocarvalho08@gmail.com

RESUMO: O trabalho explora o cabimento do Incidente de Resolução de Demandas Repetitivas (IRDR), a partir da análise de um caso concreto em diálogo com fontes normativas e doutrinárias do direito processual civil. Esta é uma pesquisa teórica com caráter majoritariamente qualitativo e prioritariamente bibliográfico, por meio de uma concatenação dos dados de jurisprudências e regimentos internos de tribunais de justiça. Imergiu-se crítica e analiticamente na aplicabilidade do IRDR na instância recursal de causas oriundas de varas especiais estaduais. Buscou-se refletir quanto à ausência de regulamentação normativa do IRDR nos juizados especiais estaduais a partir de um caso concreto.

PALAVRAS-CHAVE: IRDR, incidente, juizados especiais, aplicabilidade, turmas recursais.

ABSTRACT: This paper explores the relevance of the Incident to Solve Repeated Demands, based on the analysis of a specific case in a dialogue with normative and doctrinal sources

\footnotetext{
${ }^{1}$ Artigo recebido em 08/07/2021 e aprovado em 09/12/2021.
} 
in Brazilian civil procedural law. As for the procedures, it is a theoretical research with a qualitative character. This work sought to awaken a reflection on the absence of regulations in the special state courts, based on a concrete case with its implications and similarities with other cases in the Brazilian Judiciary.

KEYWORDS. IRDR, incident, special courts, applicability, appellative classes.

\section{INTRODUÇÃO}

A questão do Incidente de Resolução de Demandas Repetitivas (IRDR) e sua relação com as Turmas Recursais dos Juizados Especiais estaduais ainda desperta controvérsias. Com efeito, já se passaram mais de quatro anos após a previsão do IRDR instituído pelo Código de Processo Civil (CPC), promulgado em 2015, e o assunto ainda se mostra longe de estar esgotado. ${ }^{2}$ Eis, então, que emerge o objetivo do presente trabalho: analisar a legalidade e a aplicação do IRDR no que tange aos Juizados Especiais e suas respectivas Turmas Recursais.

O sistema dos Juizados Especiais tem peculiaridades dispostas em sua origem na legislação que o define, a Lei n. 9.099, como os princípios norteadores previstos em seu $\operatorname{artigo} 2^{\circ}$, a saber: oralidade, simplicidade, informalidade, economia processual e celeridade. ${ }^{3}$ A finalidade por trás desses ditames é que os Juizados Especiais tenham um funcionamento desburocratizado e os litígios tenham soluções breves, priorizando a conciliação e a transação judicial.

Outra característica especial é que o microssistema dos juizados é sua composição. Como demonstrado por Letícia Costa, em primeira instância há juízes togados e leigos; já

\footnotetext{
${ }^{2}$ Lei n. 13105, de 16 de março de 2015. Código de Processo Civil. Brasília, DF: Congresso Nacional. Disponível em: http://www.planalto.gov.br/ccivil_03/_ato2015-2018/2015/lei/113105.htm. Acesso em: 15 jul. 2020.

${ }^{3}$ Lei n. 9099, de 26 de setembro de 1995. Dispõe sobre os Juizados Especiais Cíveis e Criminais e dá outras providências. Brasília, DF: Congresso Nacional. Disponível em: http://www.planalto.gov.br/ccivil_03/leis/19099.htm. Acesso em 15 jul. 2020.
} 
em segunda instância, os juizados não correspondem a nenhum Tribunal de Justiça ou Regional Federal, mas sim a Turmas ou Colégios Recursais, ${ }^{4}$ que são compostos preferencialmente por juízes que compõem da própria estrutura dos juizados e, por conseguinte, suas decisões não podem ser revistas pelos Tribunais. Ressalta-se que as Turmas não são tribunais, como já disposto pelo enunciado n. 203 da súmula do Supremo Tribunal de Justiça (STJ), ora transcrita: "Não cabe recurso especial contra decisão proferida por órgão de segundo grau dos Juizados Especiais." Assim, o microssistema dos juizados torna-se "hermeticamente fechado" em si mesmo quanto à produção de jurisprudências. Foi por isso, com efeito, que uma decisão do STJ em relação ao tema foi escolhida como mote e como paradigma para o desenvolvimento do presente trabalho.

Nesse sentido, a análise de caso foi o método adotado para dar início ao debate de posições jurisprudenciais, contrárias e a favor, em torno do tema para estabelecer um posicionamento quanto à relação do instituto jurídico e sua aplicação na seara dos juizados. Em razão disso, pretendeu-se fazer uma revisão da literatura doutrinária do que já foi produzido pela comunidade jurídica brasileira em torno da temática.

A finalidade almejada, desse modo, foi a de buscar a ampliação das reflexões sobre o tema no campo do pensamento jurídico, visando chamar a atenção para o "vácuo legislativo" em relação à Lei n. 9.099 que existe quanto à aplicação do IRDR, o que é previsto no Código de Processo Civil de 2015. Essa situação, ato contínuo, permanece gerando dúvidas e conflitos na prática judiciária.

\section{APRESENTAÇÃO DO CASO ANALISADO}

Para o objetivo da análise de caso deste trabalho foi escolhido o Agravo Interno (AgInt) na Reclamação n. 30.988/BA, julgado em agosto de 2016 pelo Superior Tribunal de Justiça, cujo relator foi o Ministro Gurgel de Faria. ${ }^{5}$ Na decisão agravada, que foi desprovida

\footnotetext{
${ }^{4}$ COSTA, Letícia Zuccolo Paschoal da. A segurança jurídica e os Juizados Especiais: notas sobre a valorização de precedentes no novo CPC. In: DIDIER JR, Fredie (Org.). Coleção repercussões do Novo CPC: Juizados Especiais. 1. ed, p. 551-556. Salvador: JusPodivm, 2016.

${ }^{5}$ Superior Tribunal de Justiça. Agravo Interno no Agravo em Recurso Especial n. 30.988/BA. Relator: Ministro Gurgel de Faria. Brasília, DF, 10 ago. 2016. Disponível em: 
pela turma, a agravante aduziu que o acórdão impugnado divergiu da jurisprudência do STJ. Assim, transitada em julgado a decisão condenatória de primeiro grau, fica "vedado ao órgão colegiado rediscutir a matéria já decidida, sob pena de vulnerar o instituto da coisa julgada." 6

A reclamação inicialmente foi ajuizada, em março de 2013, no Juizado Especial da Bahia, em que tramitou na $2^{\text {a }}$ Vara dos Sistema dos Juizados Especiais de Salvador com o $\mathrm{n}^{\circ}$ 0018719-61.2013.805.0001. O processo versou acerca de questões de direito administrativo relacionados a serviços de ensino superior e financiamento privado de educação. A parte autora foi uma aluna universitária e as reclamadas foram o Centro Universitário Jorge Amado (UNIJORGE) e o Banco Itaucard S.A.

A questão tratada no processo era quanto a parcelas de financiamento de mensalidades universitárias a serem liberadas e pagas em caráter liminar. A decisão provisória em sede de primeiro grau deferiu que o banco reclamado pagasse as mensalidades com as multas devidas em caso de atraso. Essa decisão provisória foi mantida na sentença proferida em fevereiro de 2014. Segue recorte da referida sentença proferida pela juíza de primeiro grau do $2^{\circ}$ Juizado de Salvador, Bahia, a magistrada Michelline Luz:

Diante do exposto, JULGO PROCEDENTES os pedidos formulados na inicial, tornando definitiva a liminar concedida nestes autos, para a condenação do Banco ITAUCARD S A ao pagamento das mensalidades dos meses de janeiro, fevereiro e março de 2013. Condeno ainda as rés, solidariamente, a compensar os danos morais causado à autora, pagando cada uma delas a quantia de $\mathrm{R} \$ 750,00$ (setecentos e cinquenta reais), totalizando $\mathrm{R} \$$ $1.500,00$ (mil e quinhentos reais), corrigida monetariamente a partir do arbitramento e acrescida de juros legais a partir da citação. ${ }^{7}$

A instituição financeira, em seu direito ao contraditório, interpôs Recurso Inominado contra a sentença de piso, no que se referia à aplicação de multas astreintes. Ato contínuo, o recurso foi distribuído para julgamento da Quinta Turma Recursal do Sistema dos Juizados Especiais da Bahia. Assim, três anos após o início do processo, em fevereiro de 2016, a

https://stj.jusbrasil.com.br/jurisprudencia/514549889/agravo-interno-na-reclamacao-agint-na-rcl-34175-mg2017-0134648-1/inteiro-teor-514549898. Acesso em: 15 jul. 2020.

${ }^{6}$ Ibidem.

${ }^{7}$ Juizados Especiais Cíveis de Defesa do Consumidor, $2^{\mathrm{a}}$ Vara de Salvador, Bahia. Sentença no processo ${ }^{o}$ 0018719-61.2013.8.05.0001. Juíza prolatora Michelline Soares Bittencourt Trindade Luz. Projudi TJBA: Salvador, 25 fev. 2014. Disponível em: https://projudi.tjba.jus.br/projudi/listagens/DownloadArquivo? arquivo $=19910209$. Acesso em: 16 jul. 2020. (Grifos no original). 
Turma Recursal do Sistema dos Juizados Especiais da Bahia acolhera os argumentos da instituição financeira, derrubou a sentença do juízo a quo e determinou em seu acórdão a inexistência da obrigação de conceder crédito de financiamento, bem como reconheceu a ausência de descumprimento da liminar.

Abaixo, trecho do voto da juíza relatora Cristiane Menezes Santos Barreto que foi seguido pelos demais juízes, no acórdão proferido pela Turma Recursal baiana. Na decisão está sustentado um entendimento diametralmente oposto ao que foi proferido em sede de primeiro grau:

Por conseguinte, opino pela inexistência da obrigação de conceder crédito de financiamento a partir de 2013 e, por conseguinte, pela ausência de descumprimento da liminar e encerrada a prestação jurisdicional no feito $s u b$ examine. Assim sendo, ante ao exposto, voto no sentido de CONHECER e DAR PROVIMENTO ao recurso interposto pelo Recorrente BANCO ITAUCARD S/A, para reformar a sentença que julgou a impugnação à execução e declarar a ausência de exigibilidade do cumprimento da liminar, reconhecendo a entrega da prestação jurisdicional do presente feito. ${ }^{8}$

Teoricamente, não haveria mais recursos possíveis uma vez que foi um processo em sede do Sistema dos Juizados Especiais Estaduais. Porém, a decisão da Turma Recursal foi prolatada após a entrada em vigor do Código de Processo Civil, o qual prevê, em seu artigo 988, IV, que a jurisprudência a ser considerada para efeito do cabimento da reclamação na hipótese em exame é aquela proferida em julgamento de incidente de resolução de demandas repetitivas ou de incidente de assunção de competência.

Assim, a autora da ação teve sentença procedente deferida pelo juízo de primeiro grau e posteriormente derrubada pela Turma Recursal. Em seguida, interpôs Agravo Interno no STJ em que questionou o fato de que a Turma Recursal seria contra posicionamento consolidado pela Corte Superior. Entretanto, o tribunal superior levou em consideração o fato de que o acórdão reclamado foi oriundo de turma recursal de juizado especial e, na linha da sua própria jurisprudência (súmula n. 203), afigurava-se inviável o processamento do recurso de agravo, conforme acórdão proferido em agosto de 2016 e que é o objeto de análise deste trabalho.

\footnotetext{
${ }^{8}$ Quinta Turma Recursal Cível e Criminal dos Juizados Especiais Cíveis de Defesa do Consumidor da Bahia. Acórdão em Recurso Inominado no processo no 0018719-61.2013.8.05.0001. Juíza Relatora Cristiane Menezes Santos Barreto. Projudi TJBA: Salvador, 23 fev. 2016. (Grifos no original).
} 


\section{REVISÃO DE JURISPRUDÊNCIAS}

As jurisprudências no âmbito dos tribunais superiores brasileiros quanto ao processamento de questões envolvendo IRDR oriundas dos Juizados Especiais Estaduais são unânimes no sentido de entender que, tanto o STJ como o STF, não são competentes para decidir tais questões. Esse inclusive é o caso do acórdão paradigma em análise neste trabalho.

Diante disso, traz-se à luz dessa explanação uma decisão do Supremo Tribuna Federal que versa justamente sobre a lacuna legal quanto à unificação de demandas repetitivas em sede das Turmas dos Juizados Especiais estaduais. ${ }^{9} \mathrm{O}$ ARE pretendia que fosse resolvida a questão se haveria ou não competência do STJ para decidir IRDR oriundo dos Juizados Especiais Estaduais. Por conseguinte, ficou clara a postura da Suprema Corte no sentido de não ser cabível a instauração do IRDR perante o STJ.

A seguir, transcreve-se o trecho do acórdão que demonstra o conflito causado pela ausência de legislação:

Para suprir a lacuna da uniformização da interpretação da lei federal no âmbito dos Juizados especiais comuns, o Superior Tribunal de Justiça editou resolução, admitindo o manejo da Reclamação. Quando ainda vigorava o CPC de 1.973, a Resolução STJ n. 12/2009 admitia que fosse dirigida Reclamação a esta Corte quando decisão de Turma Recursal estadual ou do Distrito Federal a) afrontasse jurisprudência do STJ pacificada em recurso repetitivo; b) violasse súmula do STJ; ou c) fosse teratológica. 5. No entanto, após o advento do CPC/2015, a Resolução n. 12/2009 foi revogada e substituída pela Resolução n. 03/2016 que, em seu art. $1^{\circ}$, restringiu o cabimento da Reclamação dirigida a esta Corte à hipótese de decisão de Turma Recursal Estadual (ou do DF) que contrariar jurisprudência do STJ consolidada em a) incidente de assunção de competência [... $]^{10}$

Assim, após a promulgação do CPC de 2015 e a revogação da Resolução n. 12 do STJ, não existe mais a possibilidade das divergências jurisprudenciais entre as Turmas Recursais dos Juizados Especiais serem pacificadas via Pedido de Uniformização de Lei Federal perante o STJ.

\footnotetext{
${ }^{9}$ Supremo Tribunal Federal. Recurso Extraordinário com Agravo n. 0000003-10.2017.8.26.9006/SP. Relator: Ministro Celso de Melo. Brasília, DF, 29 out. 2018. Disponível em: https://stf.jusbrasil.com.br/jurisprudencia/872448694/recurso-extraordinario-com-agravo-are-1156816-spsao-paulo-0000003-1020178269006?ref=serp. Acesso em 17 jul. 2020.

${ }^{10}$ Ibidem.
} 
Não obstante, ao contrário do que alegou a reclamante da AgInt n. 30.988/BA (que é objeto deste trabalho de análise), a jurisprudência do STJ admite rever, em qualquer tempo, a multa imposta por descumprimento de obrigação de fazer, conforme precedentes que foram expostos no acórdão da decisão sob análise. A seguir, trecho do acórdão:

Processual civil. Agravo regimental no recurso especial. Energia elétrica. Astreintes. Redução do valor, pelo tribunal de origem. Possibilidade. Ofensa à coisa julgada. Inexistência. Agravo regimental improvido. I. Nos termos da jurisprudência do Superior Tribunal de Justiça, "a multa prevista no art. 461 do Código de Processo Civil não faz coisa julgada material e pode ser revista a qualquer tempo, quando se modificar a situação em que foi cominada" (STJ, AgRg no AREsp 627.474/RJ, Rel. Ministro Luis Felipe Salomão, quarta turma. Nesse sentido: STJ, REsp 1.333.988/SP, Rel. Ministro Paulo de Tarso Vieira Sanseverino, segunda seção; AgRg no AREsp 533.301/DF, Rel. Ministro Humberto Martins, segunda turma; AgRg no REsp 1.126.646/SP, Rel. Ministro Benedito Gonçalves, primeira turma, DJe de 01/12/2009. II. Agravo Regimental improvido. (AgRg no REsp 1407275/CE, rel. Min. Assusete Magalhães, segunda turma). ${ }^{11}$

Nos Tribunais de Justiça Estaduais, outrossim, os entendimentos e jurisprudências caminham em sentidos diversificados. Nos estados de Minas Gerais e de São Paulo, por exemplo, essas previsões existem nos regimentos internos dos seus Tribunais de Justiça.

Especificamente no caso da Corte de Minas Gerais, decidiu-se no sentido de fortalecer as Turmas Recursais de Unificação dos Juizados Especiais, por meio da efetivação do regimento interno do Tribunal Estadual, que prevê a composição e funcionamento dessas turmas. É o que se observa, nesse sentido, no acórdão proferido pelo Tribunal de Justiça de Minas Gerais (TJ-MG) no julgamento do IRDR n. 1.0000.16.041441-3/000, oriundo do processo que tramitou em primeiro grau com o n. 0414413-57.2016.8.13.0000.

A egrégia turma da $2^{\text {a }}$ Seção Cível do TJ-MG decidiu, no referido processo acima mencionado, que o Tribunal é incompetente para decidir IRDR originário de litígios do Juizados Especiais se baseando em dispositivo do regimento interno do TJ-MG, o qual será melhor trabalhado no tópico deste trabalho que trata das legislações. Segue trecho recortado do acórdão da Corte Mineira:

\footnotetext{
${ }^{11}$ Superior Tribunal de Justiça. Recurso Especial n. 1.631.846/DF. Relator: Ministro Paulo de Tarso Sanseverino. Brasília, DF, 05 nov. 2019. Disponível em: https://stj.jusbrasil.com.br/jurisprudencia/859905793/recurso-especial-resp-1631846-df-2016-02633544/inteiro-teor-859905868?ref=juris-tabs. Acesso em: 16 jul 2020.
} 
Por força do disposto no art. 35, II, do RITJMG, compete às seções cíveis processar e julgar o IRDR. Consoante disposição do art. 976 do CPC, diante da existência de efetiva repetição de processos ativos e do risco de ofensa à isonomia e à segurança jurídica, quando se tratar de controvérsia sobre a mesma questão unicamente de direito, admite-se seja suscitado o Incidente de Resolução de Demandas Repetitivas. ${ }^{12}$

Em outra direção está o Tribunal de Justiça do Paraná (TJ-PR), que não tem a previsão de unificação de jurisprudências em seu regimento interno. Por isso, a Corte paranaense acatou a tramitação do IRDR $\mathrm{n}^{\circ}$ 1.711.022- 8 , suscitado a partir de processos oriundos dos Juizados Especiais. O número unificado do processo no sistema do Tribunal foi 002372167.2017.8.16.0000. Segue recorte de trecho da fundamentação utilizada pelo TJ-PR para acatar a tramitação do recurso:

[...] o fato de a maioria dessas ações terem sido ajuizadas perante os Juizados Especiais não tem o condão de subtrair o reconhecimento da competência do Órgão Especial para conhecer do incidente de resolução de demandas repetitivas sobre o tema. Isso porque não existem, no sistema dos Juizados Especiais do Estado do Paraná, instrumentos de uniformização de jurisprudência ou a possibilidade de recurso aos tribunais superiores. Nesse contexto, eventual empeço à utilização do IRDR no caso examinado, poderia resultar em ofensa ao princípio da isonomia, além de grande prejuízo à sociedade. ${ }^{13}$

Pelo exposto, vê-se que a ausência de uma legislação federal que direcione os Tri-

bunais Estaduais do país quanto à tramitação do IRDR em sede de questões originadas nos Juizados Especiais dificulta a uniformização das jurisprudências nesse âmbito.

\section{ENTENDIMENTO DOUTRINÁRIO EM TORNO DO IRDR NOS JUIZADOS ES- PECIAIS ESTADUAIS}

O tema da compatibilidade do IRDR na seara dos Juizados Especiais Estaduais ainda não é tratado de forma extensa. Não é numerosa a quantidade de juristas que se debruçaram

\footnotetext{
${ }^{12}$ Tribunal de Justiça de Minas Gerais. Incidente de Resolução de Demandas Repetitivas n. 1.0000.16.041441 3/000. Relator: Desembargadora Aparecida Grossi, 2a Seção Cível. Belo Horizonte, MG, 18 out. 2018. Disponível em: https://www4.tjmg.jus.br/juridico/sf/proc_movimentacoes2.jsp?listaProcessos= 10000160414413000. Acesso em 17 jul. 2020.

${ }^{13}$ Tribunal de Justiça do Paraná. Incidente de Resolução de Demandas Repetitivas n. 1.711.022-8. Relator: Desembargadora Ruy Cunha Sobrinho. Curitiba, PR, 19 fev. 2018. Disponível em: https://www.tjpr.jus.br/documents/2640044/1 1090622/IRDR+010+-+Decisão+de+admissão+e+suspensão/ 0551aa56-667d-06cc-2430-20f74238240a. Acesso em 18 jul. 2020.
} 
especificamente sobre esse assunto, restando muito o que se trabalhar e, talvez por esse motivo, que ainda não tenha havido pressão suficiente no Poder Legislativo Federal para legislar especificamente nesse "vácuo legislativo", de modo a emendar o Código de Processo Civil de 2015, para expressamente abranger os juizados, ou uma alteração à Lei n. 9.099/1995, para adequá-la à luz da atual legislação processual mais recente.

Frisa-se que a doutrina jurídica existente sobre o tema aponta pacificamente para a aplicabilidade do IRDR nos Juizados Especiais Estaduais. O primeiro fator para esse direcionamento doutrinário é o fato de não haver óbices legais para tal aplicabilidade, apenas um vazio legal que é, por vezes, suprido pelos regimentos internos dos tribunais ou por entendimentos jurisprudenciais das Cortes Estaduais. O segundo fator é o que o IRDR é uma medida que visa garantir certa segurança jurídica nas decisões, especificamente em sede de primeiro grau dos juizados, da qual os tutelados pelas cortes especiais são, em certo nível.

Ademais, perpassar-se-á aqui pela doutrina jurídica que pode ser aproveitada para tratar do tema. Inicialmente, busca-se no pensamento do ilustre jurista Cândido Dinamarco, quando afirma necessidade incessante de adaptação, de modo a melhorar o sistema processual:

Diante do que já se viu, do que já se propôs, se discutiu, se aceitou no direito positivo e nas práticas dos juízes, é lícito afirmar que a busca de soluções de aperfeiçoamento está encetada e em plena efervescência nos escritos dos juristas e mesmo na evolução do direito processual positivo. E temos também a certeza de que todos repudiam o sistema processual e judiciário de que dispomos, sendo indispensável alguma transformação daquilo que hoje existe. ${ }^{14}$

Pensando nessas adaptações do processo civil brasileiro em relação às demandas repetitivas e a unificação de jurisprudências previsto pelo Incidente de Unificação de Jurisprudências dispostas no Código de Processo Civil, promulgado em 2015, cita-se Alexandre Câmara, quando afirma se tratar "[d]aquelas demandas idênticas, seriais, que, em grandes quantidades, são propostas perante o Judiciário." 15

Nessa linha, não se pode perder de vista a segurança jurídica. Como ressalta Luiz Guilherme Marinoni, o Poder Judiciário precisa estar atento para o fato de que as "linhas

\footnotetext{
${ }^{14}$ DINAMARCO, Cândido Rangel. Nova era do processo civil. 3. ed. São Paulo: Malheiros, 2009, p. 18-19.

${ }^{15}$ CÂMARA, Alexandre Freitas. O novo processo civil brasileiro. 2. ed. São Paulo: Atlas, 2015. p. 476
} 
decisórias inconstantes violam expetativas legítimas do jurisdicionado. Aquele que se coloca em situação similar à do caso já julgado possui legítima expectativa de não ser surpreendido por decisão diversa."16 Tem-se, desse modo, que o IRDR é mais um instrumento de garantia da segurança jurídica, especialmente quando ligado aos Juizados Especiais que atendem a demandas de massa. Muitos dos processos que tramitam nos juízos especiais são demasiado semelhantes uns com os outros. Logo, fazem jus a uma unificação jurisprudencial. Nas palavras de Duarte e Brasil, o desafio para os juristas é grande.

Contudo, temos o desafio de fazer uma nova leitura do sistema processual, calçado em valores e vetores jamais aplicados. Logo, devemos partir da premissa de maior enfrentamento das demandas de massa, utilizando os remédios processuais inovadores, algo que, certamente, não pode alienar os Juizados Especiais. Não teria o menor sentido pensar em enfrentamento de massa com uma ferramenta tão eficaz como o IRDR e não aplicá-la aos Juizados, justamente a seara mais carente de sua atuação. Seria como ter o remédio e não ministrá-lo ao paciente. ${ }^{17}$

É por isso que são muito pertinentes as palavras de Dresch, ao afirmar que "as disposições acerca do IRDR são aplicáveis aos juizados especiais. Contudo, é necessário adequá-lo, mediante regulamentação específica, às peculiaridades do microssistema". ${ }^{18}$ Por isso, como já dito, não há nada na legislação brasileira que impeça a aplicação do IRDR nos Juizados Estaduais e, por isso, como também dito por Dresch, é preciso que haja adaptação do Judiciário, "a fim de sanar certas incongruências sistêmicas e não subverter o procedimento oral e sumaríssimo, destinado a resolver com rapidez e simplicidade as causas menos complexas."19

Salienta-se que a doutrina também afirma que se não for definida uma tese jurídica para solucionar litígios repetitivos, os jurisdicionados (as partes de cada processo) podem intervir positivamente com contribuições para o convencimento do tribunal que está

\footnotetext{
${ }^{16}$ MARINONI, Luiz Guilherme. In: WAMBIER, Teresa Arruda Alvim; DIDIER JR., Fredir; DANTAS, Bruno (Coord.). Breves comentários ao novo Código de Processo Civil. São Paulo: Revista dos Tribunais, 2015.

${ }^{17}$ DUARTE, Antonio Aurelio Abi Ramia; BRASIL, Maria Eduarda de Oliveira. Os Juizados Especiais Estaduais e o IRDR: por uma busca harmônica dos mesmos objetivos. Revista de Estudos e Debates - CEDES, Rio de Janeiro, p. 79 - 101, 06 jun. 2016. Disponível em: http://www.tjrj.jus.br/documents/10136/3543964/juizados-especiais-estaduais.pdf. Acesso em: 20 jul. 2020.

18 DRESCH, Silvane. A aplicabilidade do incidente de resolução de demandas repetitivas aos juizados especiais. Revista do CEJUR/TJSC: Prestação Jurisdicional, Florianópolis, v. 4, n. 1, p. 201-223, dez. 2016. Disponível em: https://revistadocejur.tjsc.jus.br/cejur/article/view/144. Acesso em: 31 jul. 2020.

${ }^{19}$ Ibidem.
} 
enfrentando a causa, uma vez que possuem interesse jurídico no resultado do processo. Quem pensa dessa forma é Leonardo Cunha, ao dizer que

A todo sujeito interessado em determinada decisão jurisdicional deve ser concedida a possibilidade de participar no processo de sua formação, sendo-lhe reconhecido o direito de ser ouvido, a fim de poder influenciar o julgador e ajudá-lo na elaboração do conteúdo da decisão, contribuindo para a definição de sua ratio decidendi. ${ }^{20}$

Por último, não se pode esquecer de aplicar as críticas que existem ao sistema de precedente de uma maneira geral, do qual o IRDR faz parte. Para que o sistema de precedentes seja devidamente aplicado no Brasil, é fundamental que o sistema jurídico brasileiro não fuja dos princípios básicos do civil law que norteiam o Direito brasileiro. Como aponta Lênio Streck e Abboud, em artigo publicado no portal jurídico Conjur:

Para tal desiderato, cremos ser fundamental a correta noção sobre o que é efetivamente um precedente genuíno do common law e a necessária compreensão do que é um provimento vinculante por disposição legal, por exemplo, súmula vinculante, acórdão paradigma etc. O sistema genuíno de precedentes inglês é criador de complexidade. O que o CPC-2015 faz é criar provimentos judiciais vinculantes cuja função é reduzir a complexidade judicial para enfrentar o fenômeno brasileiro da litigiosidade repetitiva. Respostas antes das perguntas. Mas, não podemos equiparar o artigo 927 a um sistema de precedentes, sob pena de termos uma aplicação desvirtuada do CPC. ${ }^{21}$

Apresentados os principais apontamentos doutrinários em torno da temática proposta neste trabalho, faz-se necessário abordar as normas que preveem e regulamentam o funcionamento do IRDR no sistema jurídico brasileiro.

\section{NORMAS QUE REGULAMENTAM O IRDR}

A regulamentação do IRDR na legislação brasileira deixa cristalino o rompimento com as noções individualistas que permeavam o CPC de 1973, visando um tratamento uniforme focado na resolução de questões de direito para decidir questões semelhantes ou idênticas, de modo a não criar discrepâncias e, por consequência, insegurança jurídica.

\footnotetext{
${ }^{20}$ CUNHA, Leonardo José Carneiro da. Anotações sobre o incidente de resolução de demandas repetitivas previsto no projeto de lei do novo Código de Processo Civil. Revista de Processo. São Paulo, v. 36, n. 193, p. 255-79, mar. 2011. p. 269.

${ }^{21}$ STRECK, Lenio Luiz; ABBOUD, Georges. O que é isto: o sistema (sic) de precedentes no CPC?. Senso Incomum. Conjur: online, 18 ago. 2016. Disponível em: https://www.conjur.com.br/2016-ago-18/sensoincomum-isto-sistema-sic-precedentes-cpc. Acesso em: 25 jul. 2020.
} 
Desse modo, o CPC de 2015 soluciona dúvidas quanto à finalidade constitucional do IRDR que é conferir previsibilidade e segurança jurídica à Jurisdição e preservar a isonomia processual, com o propósito de que tanto a lei como a jurisprudência sejam claras para afastar decisões exóticas e surpreendentes à segurança jurídica. Assim, vem a disposição do artigo 976 e seguintes do CPC de 2015, estabelecendo a resolução de demandas repetitivas como um incidente que pode ser provocado perante os tribunais de segunda instância, quando houver repetição de processos com idêntica controvérsia de direito e risco de ofensa aos princípios da isonomia e da segurança jurídica. Em transcrição dos artigos do CPC de 2015 pertinentes ao tema, primeiro o próprio artigo 976, com destaque para o inciso II (risco de ofensa à isonomia e segurança jurídica) e para o parágrafo $5^{\circ}$ (não haverá custas processuais no IRDR), tem-se que

É cabível a instauração do incidente de resolução de demandas repetitivas quando houver, simultaneamente: I - efetiva repetição de processos que contenham controvérsia sobre a mesma questão unicamente de direito; II risco de ofensa à isonomia e à segurança jurídica. $\S 1^{\circ} \mathrm{A}$ desistência ou o abandono do processo não impede o exame de mérito do incidente. $\S 2^{\circ} \mathrm{Se}$ não for o requerente, o Ministério Público intervirá obrigatoriamente no incidente e deverá assumir sua titularidade em caso de desistência ou de abandono. $\S 3^{\circ} \mathrm{A}$ inadmissão do incidente de resolução de demandas repetitivas por ausência de qualquer de seus pressupostos de admissibilidade não impede que, uma vez satisfeito o requisito, seja o incidente novamente suscitado. $\S 4^{\circ}$ É incabível o incidente de resolução de demandas repetitivas quando um dos tribunais superiores, no âmbito de sua respectiva competência, já tiver afetado recurso para definição de tese sobre questão de direito material ou processual repetitiva. $\S 5^{\circ}$ Não serão exigidas custas processuais no incidente de resolução de demandas repetitivas. (BRASIL, 2015, online).

Também não se pode deixar de mencionar o artigo 977 do códex processual, que estabelece a quem será dirigido o incidente. Esse artigo pode ser utilizado de forma análoga e com a devida hermenêutica na aplicação do IRDR à jurisdição da Lei n. 9.099, de 1995:

Art. 977. O pedido de instauração do incidente será dirigido ao presidente de tribunal: I - pelo juiz ou relator, por ofício; II - pelas partes, por petição; III - pelo Ministério Público ou pela Defensoria Pública, por petição. Parágrafo único. $\mathrm{O}$ ofício ou a petição será instruído com os documentos necessários à demonstração do preenchimento dos pressupostos para a instauração do incidente. (BRASIL, 2015, online).

No âmbito dos Juizados Especiais Federais, a questão já é pacificada pela norma que os criou, especificamente a Lei n. 10.259 de 2001, no seu artigo 14, o qual dispõe o que 
segue: "Caberá pedido de uniformização de interpretação de lei federal quando houver divergência entre decisões sobre questões de direito material proferidas por Turmas Recursais na interpretação da lei." (BRASIL, 2001).

Os Juizados Especiais da Fazenda Pública também têm previsão legal quanto à uniformização jurisprudencial na Lei Ordinária n. 12.153, de 2009, que dispõe sobre os Juizados Especiais da Fazenda Pública no âmbito dos Estados, do Distrito Federal, dos Territórios e dos Municípios. ${ }^{22}$ Especificamente o artigo 18 da mencionada lei dispõe, em seu caput, que "Caberá pedido de uniformização de interpretação de lei quando houver divergência entre decisões proferidas por Turmas Recursais sobre questões de direito material."

Já a Lei n. 9.099/95, que prevê a criação dos Juizados Especiais Estaduais, não possui previsão em torno da unificação de entendimentos produzidos nas Turmas Recursais dos Juizados Especiais. É partindo dessa lacuna que alguns tribunais de justiça dos estados brasileiros passaram a dispor nos seus regimentos internos acerca da unificação jurisprudencial, como é o caso do Tribunal de Justiça de Minas Gerais (TJ-MG) e do Tribunal de Justiça de São Paulo (TJ-SP), por exemplo.

O regimento interno do TJ-MG, por sua vez, prevê em sua seção IX, a competência da Turma de Uniformização de Jurisprudência dos Juizados Especiais. Nessa seção, há apenas o artigo 42, suficiente para definir a função da Turma de Uniformização e seu procedimento, in verbis: “Compete à Turma de Uniformização de Jurisprudência uniformizar jurisprudência em caso de divergência de tese entre duas ou mais turmas recursais do Estado, nos termos da legislação pertinente." 23

Vale mencionar ainda os enunciados do Fórum Nacional de Juizados Especiais (FONAJE) e seu efeito sobre de unificação jurisprudencial em torno da lei 9.099/95. ${ }^{24}$ Apesar

\footnotetext{
${ }^{22}$ Lei n. 12153 de 22 de dezembro de 2009. Dispõe sobre os Juizados Especiais da Fazenda Pública no âmbito dos Estados, do Distrito Federal, dos Territórios e dos Municípios. Brasília, DF: Congresso Nacional. Disponível em: http://www.planalto.gov.br/ccivil_03/_ato2007-2010/2009/lei/112153.htm. Acesso em: 16 jul. 2020.

${ }^{23}$ Tribunal de Justiça De Minas Gerais. Regimento interno do Tribunal de Justiça do Estado de Minas Gerais. Belo Horizonte, MG, 2012. Disponível em: http://www.tjmg.jus.br/portal-tjmg/atos-normativos/regimentointerno-1.htm. Acesso em: 28 jul. 2020.

${ }^{24}$ Todos os enunciados do FONAJE, que são amplamente utilizados pelos magistrados na seara dos Juizados Especiais Estaduais, estão disponíveis para consulta em sua página online: https://www.amb.com.br/fonaje/?p=32.
} 
dos enunciados não serem leis, são utilizados na prática jurídica pelos magistrados dos juizados especiais como se fossem normas promulgadas pelo poder legislativo, como se fossem parte da legislação pátria. Ressalta-se que este trabalho não pretende fazer especificamente juízos de valor quanto a essa prática corrente dos magistrados. Contudo, considerando a forma de vinculação a qual os enunciados do FONAJE são utilizados nas sentenças e nos acórdãos das turmas recursais, optou-se por falar sobre o tema neste tópico que trata da legislação.

Ora, muito mais coerente ao sistema jurídico brasileiro seria que esse tipo de unificação de interpretação jurisprudencial fosse feita por procedimentos que preveem garantias processuais constitucionais, como o princípio do contraditório que é cabível ao IRDR, e não por meio de reuniões de magistrados decidindo seus enunciados unilateralmente.

Salienta-se, por oportuno, que existe um projeto de lei tramitando (PL) desde 2017 na Congresso Nacional que prevê alterações na Lei n. 9.099/95 e, especificamente no seu artigo $4^{\circ}$, dispõe sobre a adequação ao Código de Processo Civil de 2015 e regulamenta o IRDR nos Juizados Especiais Estaduais. O PL, de autoria da ex-deputada Tereza Cristina, já foi aprovado na Câmara dos Deputados, em 2019, e atualmente está em trâmite de aprovação no Senado Nacional. Segue o trecho que tipifica o IRDR nos Juizados Especiais Estaduais:

Art. 4 -A. Aplicam-se, a demandas e processos no âmbito dos juizados especiais cíveis, as normas relativas a conexão e continência de ações e ao incidente de resolução de demandas repetitivas previstas na Lei n o 13.105, de 16 de março de 2015 - Código de Processo Civil, ressalvado o disposto no art. 18 desta Lei. Parágrafo único. O pedido de instauração de incidente de resolução de demandas repetitivas formulado em razão de demanda proposta perante juizado especial cível também será dirigido ao presidente de tribunal e apreciado e resolvido nos termos das regras previstas no art. 976 e seguintes da Lei n o 13.105, de 16 de março de 2015 - Código de Processo Civil. ${ }^{25}$

Esse projeto de lei, por fim, é o mais coerente e mais próximo que a legislação brasileira está de finalmente tipificar o trâmite do IRDR nos juizados regidos pela Lei 9.099/95.

\footnotetext{
${ }^{25}$ CRISTINA, Tereza. Projeto de Lei n.7483, de 2017. Acresce dispositivos à Lei no 9.099, de 26 de setembro de 1995, que "Dispõe sobre os Juizados Especiais Cíveis e Criminais e dá outras providências". Brasília: Câmara, 29 abr. 2017. Disponível em: https://www.camara.leg.br/proposicoesWeb/fichadetramitacao?id Proposicao=2131057. Acesso em: 21 jan. 2019.
} 


\section{ANÁLISE CRÍTICA SOBRE O CABIMENTO DO IRDR NOS JUIZADOS ESPE- CIAIS ESTADUAIS}

Volta-se a atenção, afinal, para o acórdão do STJ no Agravo Interno (AgInt) na Reclamação n. 30.988/BA, escolhido como ponto de partida e como paradigma para este trabalho. A posição da Corte Superior é adequada, mantendo-se coerente à Súmula n. 203, que é clara no sentido de não aceitar recurso especial contra decisão proferida por órgão de segundo grau dos Juizados Especiais. Do mesmo modo, entretanto, expõe a ausência de possibilidade de um julgamento de terceiro grau com vistas a unificar as jurisprudências dos juizados especiais, como é cabível às outras instâncias do Poder Judiciário, de acordo com a Carta Constitucional de 1988 e do Código de Processo Civil de 2015.

Apesar de se manter alinhada a sua jurisprudência, essa decisão do STJ também expõe uma espécie de "regime de exceção" em relação à possibilidade de unificação jurisprudencial a qual as instâncias especiais estaduais do microssistema regido pela Lei 9.099/95 estão inseridas.

A Corte também afirma, no acórdão do AgInt n. 30.988/BA, que nem mesmo à luz do Código de Processo Civil de 1973 e suas resoluções, que já estavam revogados à época do julgamento, seria possível acolher o recurso pretendido pela autora:

É que, a teor do art. 988, IV, do CPC/2015 (com a redação dada pela Lei n. 13.256/2016), a jurisprudência a ser considerada para efeito do cabimento da reclamação na hipótese em exame é aquela proferida em julgamento de incidente de resolução de demandas repetitivas ou de incidente de assunção de competência. Ainda que se tomasse como base a resolução revogada, melhor sorte não contemplaria a reclamante, porquanto o descompasso da decisão impugnada deveria se dar em relação a entendimento desta Corte consubstanciado em súmulas ou teses adotadas no julgamento de recursos repetitivos (CPC/1973, art. 543-C) ${ }^{26}$

Importante salientar que a noção de regime de exceção aqui empregada se deve ao fato do CPC de 2015 tratar das demais jurisdições e ser silente quanto ao tema nos juizados especiais. Tanto que alguns tribunais estaduais, como o Tribunal de Justiça de Minas Gerais

\footnotetext{
${ }^{26}$ Superior Tribunal de Justiça. Agravo Interno no Agravo em Recurso Especial n. 30.988/BA. Relator: Ministro Gurgel de Faria. Brasília, DF, 10 ago. 2016. Disponível em: https://stj.jusbrasil.com.br/jurisprudencia/514549889/agravo-interno-na-reclamacao-agint-na-rcl-34175-mg2017-0134648-1/inteiro-teor-514549898. Acesso em: 15 jul. 2020.
} 
(TJ-MG), como já mencionado no tópico 4 deste artigo, e o Tribunal de Justiça de São Paulo (TJ-SP) passaram a prever nos seus regimentos internos a competência das Turmas Recursais dos Juizados Especiais. Com o intuito de demonstrar esse fato, segue abaixo o artigo 190, junto com o seu $\S 1^{\circ}$, recortados do regimento interno do TJ-SP quanto aos trâmites do IRDR oriundos dos Juizados Especiais Estaduais:

Art. 190. A uniformização de jurisprudência será por súmulas, por enunciado de jurisprudência pacificada, por enunciado de tese jurídica fixada em incidente de resolução de demandas repetitivas e em incidente de assunção de competência. $\S 1^{\circ}$ As súmulas serão aprovadas pelo Órgão Especial, que as editará, com exclusividade; os enunciados o serão pelas Turmas Especiais, pelos Grupos de Câmaras, na hipótese do artigo 32 § $4^{\circ}$ deste Regimento, ou pelo Órgão Especial, quando se tratar de matéria constitucional, ou de matéria de sua competência, dos Juizados Especiais e da Câmara Especial, bem como de competência não exclusiva de uma das Turmas Especiais de suas Seções ou se houver divergência. ${ }^{27}$

Em outra esteira, o Tribunal de Justiça do Paraná (TJ-PR) decidiu que quem julga IRDR oriundo das Turmas Recursais dos Juizados é a própria Corte do TJ-PR, como demonstrado no tópico 3. Já o Tribunal de Justiça do Estado da Bahia (TJ-BA), por exemplo, em direção oposta, não tem nenhuma previsão quanto à tramitação e ao julgamento de IRDR oriundo dos Juizados Especiais Estaduais, seja no seu regimento interno, seja na jurisprudência do TJ-BA que versa apenas quanto ao indeferimento das ações que vêm dos juizados.

Assim, a interpretação do STJ no acórdão analisado no AgInt n. 30.988/BA é acertada, pois o foco da Corte Superior não é dirimir questões oriundas dos juizados regidos pela Lei 9.099/95, como foi o caso do litígio que deu origem ao recurso especial em escopo. Dessa forma, foi uma decisão de acordo com a súmula n. 203 supramencionada, mantendo a coerência da Corte e não ferindo nenhum princípio ou ditame constitucional.

Diante do CPC de 2015, gerou-se o que se pode chamar de "vácuo legislativo", que se forma quanto à unificação das jurisprudências via IRDR nos juizados especiais estaduais. O órgão jurisdicional que poderia solucionar a questão suscitada no AgInt n. 30.988/BA poderiam ser as próprias Turmas Recursais dos juizados especiais, se houvesse previsão do

\footnotetext{
${ }^{27}$ Tribunal de Justiça de São Paulo. Regimento interno do Tribunal de Justiça do Estado de São Paulo. São Paulo, SP, 2017. Disponível em: http://www.tjsp.jus.br/download/CanaisComunicacao/Normas SegundaInstancia/NormasTrabalho/Links/arts.\%20190\%20a\%20192\%20ritjsp.pdf. Acesso em: 29 jul. 2020.
} 
regimento interno do TJ-BA, já que o processo se originou nos juizados especiais da Bahia. Essa possibilidade de unificação é a que já ocorre no TJ-SP e no TJ-MG, por exemplo.

Outra possibilidade poderia ser o enfrentamento do caso pelo próprio TJ-BA, se houvesse jurisprudência daquele Tribunal nesse sentido, como faz o TJ-PR, após entendimentos jurisprudenciais nesse sentido. Todavia, não há nenhuma dessas duas possibilidades para unificar as jurisprudências nos Juizados Especiais Estaduais da Bahia, levando a crer que foi por essa razão que o autor da ação optou por levar o caso ao Superior Tribunal de Justiça.

O Superior Tribunal de Justiça já enfrenta um volume de processos muito grande e se toda questão dos juizados pudesse subir ao STJ haveria um número massivo de questões a serem julgadas, um fato sem precedentes, visto que os juizados especiais tratam de causas de menor complexidade de todo país e têm capacidade de solucionar tais questões per si. É nesse sentido que Brasil e Duarte acertadamente expõem quanto ao microssistema regido pela Lei n. 9.099/95:

Contudo, temos o desafio de fazer uma nova leitura do sistema processual, calçado em valores e vetores jamais aplicados. Logo, devemos partir da premissa de maior enfrentamento das demandas de massa, utilizando os remédios processuais inovadores, algo que, certamente, não pode alienar os Juizados Especiais. Não teria o menor sentido pensar em enfrentamento de massa com uma ferramenta tão eficaz como o IRDR e não aplicá-la aos Juizados, justamente a seara mais carente de sua atuação. Seria como ter o remédio e não ministrá-lo ao paciente. ${ }^{28}$

Por fim, é cristalino que não cabe ao STJ decidir a questão que foi proposta no AgInt n. 30.988/BA. Não há como negar que o mais correto seria que as Turmas Recursais do TJBA ou o próprio Tribunal baiano enfrentassem a questão. No entanto, sem previsões legais, regimentais ou sequer jurisprudenciais, os cidadãos jurisdicionados ficam sem possibilidade de ter a jurisprudência unificada.

\section{CONCLUSÃO}

\footnotetext{
${ }^{28}$ DUARTE, Antonio Aurelio Abi Ramia; BRASIL, Maria Eduarda de Oliveira. Os Juizados Especiais Estaduais e o IRDR: por uma busca harmônica dos mesmos objetivos. Revista de Estudos e Debates - CEDES, Rio de Janeiro, p. 79 - 101, 06 jun. 2016. Disponível em: http://www.tjrj.jus.br/documents/10136/3543964/juizados-especiais-estaduais.pdf. Acesso em: 20 jul. 2020.p. 91.
} 
É notável, diante do exposto, que o artigo 988, IV, do CPC de 2015 trouxe a possibilidade de cabimento da reclamação na hipótese de julgamento de incidente de resolução de demandas repetitivas ou de incidente de assunção de competência que, tecnicamente deve tramitar e ser julgado pelo tribunal superior em que tramita o processo. Por outro lado, restou incompatível com a Lei n. 9.099/95 e a aplicação do IRDR nos Juizados Especiais Estaduais.

O acórdão paradigma proferido pelo STJ no processo AgInt n. 30.988/BA, no sentido de não dar procedimento ao IRDR oriundo de processo dos Juizados Especiais Estaduais, se mostrou coerente com a legislação vigente, bem como com a própria jurisprudência da Corte Superior. Entretanto, deixa claro um dos dilemas enfrentados pelos Tribunais de Justiça do Brasil após a entrada em vigor do CPC de 2015, que não previu um procedimento unificado em relação às formas de unificação jurisprudencial nos Juizados Especiais Estaduais.

Dessa forma, alguns TJ brasileiros vão resolvendo esse dilema da forma que enxergam ser melhor: com previsões nos seus regimentos internos (como ocorre no TJ-MG e no TJ-SP) ou com jurisprudências nas próprias cortes de segundo grau (como ocorre no TJ-PR). Já outros, como é o caso do TJ-BA, sequer chegaram a enfrentar o tema, trazendo transtornos aos jurisdicionados que esperam uma unificação jurisprudencial em temas que envolvem questões massivas, como são as dos Juizados Especiais Estaduais.

É perfeitamente possível que as disposições acerca do IRDR sejam passíveis de aplicação nos juizados especiais. Contudo, faz-se necessário que sejam operadas as adequações necessárias, mediante regulamentação legal específica às peculiaridades do microssistema, a fim de sanar todas incongruências sistêmicas, sem subverter os procedimentos oral e sumaríssimo. A ideia é, dessa forma, resolver com rapidez e simplicidade as causas menos complexas.

Por último, enquanto não houver uma lei federal que tipifique a forma como os Juizados Especiais Estaduais unificam suas jurisprudências, especialmente em relação aos trâmites do IRDR, haverá insegurança jurídica quanto ao tema abordado neste artigo. Há que se esperar que medidas como a da PL n. 7.483, de 2017, em tramitação no Congresso Nacional, entrem em vigor para modificar o microssistema da Lei n. 9.099/95, para que seja atualizada quanto aos procedimentos de unificação jurisprudencial nas instâncias especiais estaduais, conforme está previsto no CPC de 2015. 


\section{REFERÊNCIAS:}

BRASIL. Constituição da República Federativa do Brasil de 1988. Diário Oficial da União, Brasília, DF, 05 out. 1988. Disponível em: http://www.planalto.gov.br/ccivil_03/constituicao/constituicaocompilado.htm. Acesso em 20 jul. 2020.

CÂMARA, Alexandre Freitas. O novo processo civil brasileiro. 2. ed. São Paulo: Atlas, 2015.

COSTA, Letícia Zuccolo Paschoal da. A segurança jurídica e os Juizados Especiais: notas sobre a valorização de precedentes no novo CPC. In: DIDIER JR, Fredie (Org.). Coleção repercussões do Novo CPC: Juizados Especiais. 1.ed, vol, p. 551-556. 7. Salvador: JusPodivm, 2016.

CRISTINA, Tereza. Projeto de Lei n.7483, de 2017. Acresce dispositivos à Lei no 9.099, de 26 de setembro de 1995, que "Dispõe sobre os Juizados Especiais Cíveis e Criminais e dá outras providências". Brasília: Câmara, 29 abr. 2017. Disponível em: https https://www.camara.leg.br/proposicoesWeb/fichadetramitacao?idProposicao=2131057. Acesso em: 21 jan. 2019.

CUNHA, Leonardo José Carneiro da. Anotações sobre o incidente de resolução de demandas repetitivas previsto no projeto de lei do novo Código de Processo Civil. Revista de Processo. São Paulo, v. 36, n. 193, p. 255-79, mar. 2011.

DINAMARCO, Cândido Rangel. Nova era do processo civil. 3. ed. São Paulo: Malheiros, 2009, p. 18-19.

DRESCH, Silvane. A aplicabilidade do incidente de resolução de demandas repetitivas aos juizados especiais. Revista do CEJUR/TJSC: Prestação Jurisdicional, Florianópolis, v. 4, n. 1, p. 201-223, dez. 2016. Disponível em: https://revistadocejur.tjsc.jus.br/cejur/article/view/144. Acesso em: 31 jul. 2020.

DUARTE, Antonio Aurelio Abi Ramia; BRASIL, Maria Eduarda de Oliveira. Os Juizados Especiais Estaduais e o IRDR: por uma busca harmônica dos mesmos objetivos. $R e$ - 
vista de Estudos e Debates - CEDES, Rio de Janeiro, p. 79 - 101, 06 jun. 2016. Disponível em: http://www.tjrj.jus.br/documents/10136/3543964/juizados-especiais-estaduais.pdf. Acesso em: 20 jul. 2020.

MARINONI, Luiz Guilherme. In: WAMBIER, Teresa Arruda Alvim; DIDIER JR., Fredir; DANTAS, Bruno (Coord.). Breves comentários ao novo Código de Processo Civil. São Paulo: Revista dos Tribunais, 2015.

STRECK, Lenio Luiz; ABBOUD, Georges. O que é isto: o sistema (sic) de precedentes no CPC?. Senso Incomum. Conjur: online, 18 ago. 2016. Disponível em: https://www.conjur.com.br/2016-ago-18/senso-incomum-isto-sistema-sic-precedentes-cpc. Acesso em: 25 jul. 2020. 